\title{
Crystal structure and size effects on the performance of $\mathrm{Li}\left[\mathrm{Ni}_{1 / 3} \mathrm{Co}_{1 / 3} \mathrm{Mn}_{1 / 3}\right] \mathrm{O}_{2}$ cathodes
}

\author{
Jianxin Zhu \\ University of California-Riverside, Material Science and Engineering Program, Riverside, \\ California 92521, United States
}

Kevin Yoo

Department of Chemical and Environmental Engineering, University of California-Riverside, Riverside, California 92521, United States

\begin{abstract}
Akhila Denduluri
Department of Bioengineering, University of California-Riverside, Riverside, California 92521, United States

Wenting Hou

Department of Chemical and Environmental Engineering, University of California-Riverside, Riverside, California 92521, United States

Juchen Guo and David Kisailus ${ }^{\text {a) }}$

University of California-Riverside, Material Science and Engineering Program, Riverside, California 92521, United States; and Department of Chemical and Environmental Engineering, University of California-Riverside, Riverside, California 92521, United States
\end{abstract}

(Received 16 August 2014; accepted 11 November 2014)

\begin{abstract}
We have investigated the effects of crystal structure and size of $\mathrm{Li}\left[\mathrm{Ni}_{1 / 3} \mathrm{Co}_{1 / 3} \mathrm{Mn}_{1 / 3}\right] \mathrm{O}_{2}(\mathrm{~L} 333)$ cathodes on the performance of lithium-ion batteries. Cation ordering and particle sizes were determined as a function of annealing temperature with subsequent electrochemical performance monitored by cyclic voltammetry (CV) and charge-discharge testing. With increasing annealing temperature, L333 exhibits a greater cation ordering, which subsequently benefitted cell performance. However, higher annealing temperatures yielded larger crystal sizes, which resulted in a decrease in high rate discharge capacity and a significant capacity fade. This is attributed to an increase in lattice parameter and volume expansion during cycling, with the largest crystal sizes displaying the most significant structural changes due to the lower strain accommodation.
\end{abstract}

\section{INTRODUCTION}

$\mathrm{Li}\left[\mathrm{Ni}_{1 / 3} \mathrm{Co}_{1 / 3} \mathrm{Mn}_{1 / 3}\right] \mathrm{O}_{2}$ (L333) was introduced by Ohzuku and Makimura in 2001 as an alternative layered cathode material by mixing three metal precursors by a solid state method. ${ }^{1}$ Since then, $\mathrm{Li}\left[\mathrm{Ni}_{1 / 3} \mathrm{Co}_{1 / 3} \mathrm{Mn}_{1 / 3}\right] \mathrm{O}_{2}$ has drawn much attention as it exhibits much higher capacity close to $200 \mathrm{~mA} \mathrm{~h} / \mathrm{g}$ with enhanced safety. ${ }^{2-4}$ Thus, it proves to be a promising cathode candidate in battery applications. Electronic structural studies have shown that $\mathrm{L} 333$ consists of $\mathrm{Ni}^{2+}, \mathrm{Co}^{3+}$, and $\mathrm{Mn}^{4+}$ species. Therefore, the reversible capacity involves the oxidation of $\mathrm{Ni}^{2+}$ to $\mathrm{Ni}^{4+}$ in the initial stage while $\mathrm{Co}^{3+}$ oxidizes to $\mathrm{Co}^{4+}$ in the later stages. ${ }^{5,6}$ Thus, its higher capacity is related to the improved chemical stability from the $\mathrm{Ni}^{2+/ 3+}$ and the $\mathrm{Ni}^{3+/ 4+}$ redox couples relative to that of the $\mathrm{Co}^{3+/ 4+}$ redox couple. Despite these advantages, $\mathrm{Li}\left[\mathrm{Ni}_{1 / 3} \mathrm{Co}_{1 / 3} \mathrm{Mn}_{1 / 3}\right] \mathrm{O}_{2}$ displays a fading effect of discharge capacities under high rate current

\footnotetext{
a) Address all correspondence to this author.

e-mail: david@engr.ucr.edu

DOI: $10.1557 / \mathrm{jmr} .2014 .370$
}

densities. ${ }^{7}$ The addition of dopants, ${ }^{8,9}$ the optimization of $\mathrm{Li}\left[\mathrm{Ni}_{1 / 3} \mathrm{Co}_{1 / 3} \mathrm{Mn}_{1 / 3}\right] \mathrm{O}_{2}$ morphology, ${ }^{10,11}$ and coatings have been studied to improve its performance during cycling at high rates. ${ }^{12-14}$

The performance of $\mathrm{Li}\left[\mathrm{Ni}_{1 / 3} \mathrm{Co}_{1 / 3} \mathrm{Mn}_{1 / 3}\right] \mathrm{O}_{2}$ is directly related to its crystal size, particle morphology, surface area, and cation mixing, which is dependent on the synthesis method. ${ }^{15,16}$ These methods have included coprecipitation, ${ }^{17}$ sol-gel, ${ }^{18}$ solid-state,${ }^{19}$ hydrothermal, ${ }^{20}$ microemulsion, ${ }^{21}$ and pyrolysis processes. ${ }^{22}$ Much of the focus has been on improving performance by introducing novel synthesis methods, such as $\mathrm{Wu}$ et al., who synthesized nanoporous L333 by using vapor grown carbon fibers as templates, ${ }^{23}$ by applying $\mathrm{ZrFx}$, carbon, or $\mathrm{Al}_{2} \mathrm{O}_{3}$ coatings, ${ }^{12-14}$ and by adding dopants of $\mathrm{Sn}$ or Al. ${ }^{8,9}$ At the same time, it is critical to investigate the performance degradation mechanism along with all of these efforts. Manthiram and $\mathrm{Choi}^{24}$ discussed the irreversible capacity loss after the first cycle in layered $\mathrm{LiNi}_{1 / 3} \mathrm{Co}_{1 / 3} \mathrm{Mn}_{1 / 3} \mathrm{O}_{2}$ cathodes at various annealing temperatures. Recently, Ghosh and $\mathrm{Kabi}^{25}$ reported the relationship between the crystal structure of L333 and calcination conditions using oxalate precursors. 
However, there is very limited information about the longer term performance and degradation of $\mathrm{Li}\left[\mathrm{Ni}_{1 / 3} \mathrm{Co}_{1 / 3} \mathrm{Mn}_{1 / 3}\right] \mathrm{O}_{2}$ cathodes. Based on our initial findings of the crystal growth mechanisms of L333, ${ }^{26}$ we perform a thorough investigation of the structure-performance relationships, which is of fundamental importance not only for its intrinsic scientific interest but also for its technological significance. ${ }^{27,28}$ The information revealed by this study will help to develop design strategies for cathodes that will enable high efficiency lithium-ion transport and extended lifetime batteries.

\section{METHODS}

\section{A. Preparation of materials}

L333 powders were prepared using a two-step coprecipitation method. Stoichiometric amounts of nickel, cobalt, and manganese nitrates $(99.5 \%$ purity, Aldrich Chemical Co.) were thoroughly dissolved in deionized water to achieve a homogeneously mixed $100 \mathrm{mM}$ solution, followed by adding a small quantity of $2 \mathrm{M} \mathrm{NaOH}$ to adjust the solution $\mathrm{pH}$ to 10 , thus, inducing precipitation. The resultant suspension was subsequently stirred at $600 \mathrm{rpm}$ under a nitrogen atmosphere at room temperature for $1 \mathrm{~h}$. The $\left(\mathrm{Ni}_{1 / 3} \mathrm{Co}_{1 / 3} \mathrm{Mn}_{1 / 3}\right)(\mathrm{OH})_{2}$ precipitate (i.e., precursor) was washed with DI water 3 times followed by a wash with pure ethanol, then dried under vacuum at $70{ }^{\circ} \mathrm{C}$ for $12 \mathrm{~h}$. The precursor was then mixed with a $5 \mathrm{wt} \%$ excess of $\mathrm{LiOH} \cdot \mathrm{H}_{2} \mathrm{O}$ and subsequently ground with a mortar and pestle. The mixture was placed in an alumina boat and annealed in a tube furnace at different temperatures (i.e., $750-1000{ }^{\circ} \mathrm{C}$ ) for $3 \mathrm{~h}$ in air.

\section{B. Material characterization}

Phase identification was determined by x-ray diffraction analysis (XRD, PANalytical Empyrean, Almelo, The Netherlands) using Ni-filtered $\mathrm{Cu} \mathrm{K} \alpha$ radiation at $45 \mathrm{kV}$ and $40 \mathrm{~mA}$ from $10-70^{\circ}(2 \theta)$. Using the resulting XRD diffraction patterns, crystallite diameters were calculated based on the Scherrer formula. Particle sizes and morphologies were observed using a scanning electron microscope (SEM, FEI XL30, Eindhoven, The Netherlands) at an accelerating voltage of $10 \mathrm{kV}$. The surface area of each sample was determined via BET nitrogen adsorption at $77 \mathrm{~K}$ using a Micromeritics Tristar 3000 .

\section{Electrochemical performance}

To test the electrochemical performance, coin cells were fabricated. As-synthesized $\mathrm{Li}\left[\mathrm{Ni}_{1 / 3} \mathrm{Co}_{1 / 3} \mathrm{Mn}_{1 / 3}\right] \mathrm{O}_{2}$ powder, conductive carbon black (Super $\mathrm{P}$ ), and polyvinylidene fluoride (PVDF) (70:20:10 in wt\%) were mixed in N-methylpyrrolidone (NMP) to produce a slurry. This viscous slurry was subsequently coated on an aluminum foil current collector and dried in a vacuum oven at $100{ }^{\circ} \mathrm{C}$ for $12 \mathrm{~h}$. A R2032 type of coin cell was assembled in an argon-filled glove box, consisting of the prepared positive electrode, lithium metal foil as the counter electrode, a Celgard polymer film as a separator, and 1.0 $\mathrm{M} \mathrm{LiPF}_{6}$ in ethylene carbonate (EC)-diethyl carbonate (DEC) $(50: 50$ in vol\%) as the electrolyte solution. The loading of the active material was $2 \mathrm{mg} / \mathrm{cm}^{2}$. The cyclic performance and rate capability of batteries were tested using an Arbin battery test system (Arbin Instruments, Model BT2043) in the voltage range of $2.8-4.5 \mathrm{~V}$ at $25^{\circ} \mathrm{C}$. Cyclic voltammograms (CVs) of $\mathrm{Li}\left[\mathrm{Ni}_{1 / 3} \mathrm{Co}_{1 / 3} \mathrm{Mn}_{1 / 3}\right] \mathrm{O}_{2}$ were recorded on a VMP3 multichannel electrochemical station (Bio-logic, Claix, France) in the voltage range of $2.8-4.5 \mathrm{~V}$ at a scan rate of $0.1 \mathrm{mV} / \mathrm{s}$.

\section{RESULTS AND DISCUSSION}

\section{A. Characterization of synthesized $\mathrm{Li}\left[\mathrm{Ni}_{1 / 3} \mathrm{Co}_{1 / 3} \mathrm{Mn}_{1 / 3}\right] \mathrm{O}_{2}$}

XRD patterns of $\mathrm{Li}\left[\mathrm{Ni}_{1 / 3} \mathrm{Co}_{1 / 3} \mathrm{Mn}_{1 / 3}\right] \mathrm{O}_{2}$ annealed in air for $3 \mathrm{~h}$ with increasing temperature are shown in Fig. 1. All peaks from L333 were indexed on the basis of the hexagonal $\alpha-\mathrm{NaFeO}_{2}$ structure with the $R \overline{3} m$ space group. Indexing of these diffraction patterns confirmed the formation of the layered L333 structure without any detectable impurities. All of the samples displayed doublet peaks for the $(006) /(102)$ at $37^{\circ}(2 \theta)$ and the $(108) /(110)$ reflections at $65^{\circ}(2 \theta)$, an indication of ordering of the hexagonal layered structures. ${ }^{6}$

This reduction of cationic mixing enabled a more efficient intercalation and deintercalation of lithium ions inside the host matrix, leading to improved electrochemical performance. ${ }^{29}$

It is also clear that with increasing annealing temperature, the peak-splitting became more pronounced, indicating an increased cationic ordering. Besides peak splitting, the ratio of the intensities of the (003) to (104) indices (i.e., $\left.I_{(003)} / I_{(104)}\right)$ is an indicator of cation mixing in materials with a layered structure. For example, a ratio of $I_{(003)} / I_{(104)}>1.2$ indicates lower cation mixing with highly ordered structures. ${ }^{18}$ From Table I, we can clearly see that the ratios of $I_{(003)} / I_{(104)}$ at 750,850 , 950 , and $1000{ }^{\circ} \mathrm{C}$ are $1.19,1.28,1.49$, and 1.47 , respectively, demonstrating an increase in cationic ordering with temperature and confirming results from the peak splitting analyses.

SEM micrographs of specimens annealed in air at different temperatures are illustrated in Fig. 2. As expected, the micrographs show that the particle sizes increase with increasing annealing temperature. Confirmation of the particle crystallinity was demonstrated by TEM from previous work, ${ }^{26}$ which revealed 


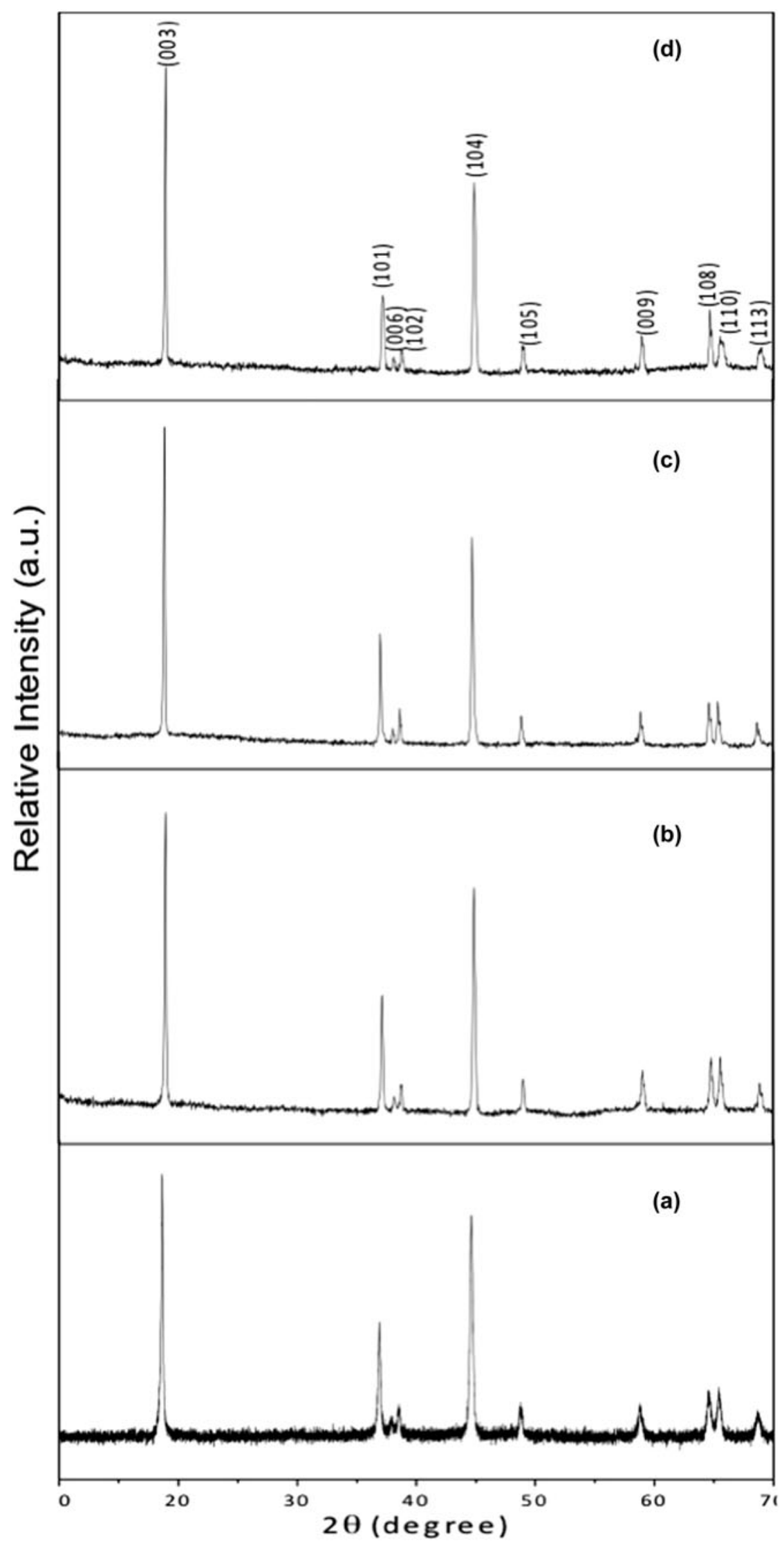

FIG. 1. XRD patterns of $\mathrm{Li}\left[\mathrm{Ni}_{1 / 3} \mathrm{Co}_{1 / 3} \mathrm{Mn}_{1 / 3}\right] \mathrm{O}_{2}$ annealed in air for $3 \mathrm{~h}$ at (a) $750{ }^{\circ} \mathrm{C}$, (b) $850{ }^{\circ} \mathrm{C}$, (c) $950{ }^{\circ} \mathrm{C}$, and (d) $1000{ }^{\circ} \mathrm{C}$. 
TABLE I. Calculated lattice parameters.

\begin{tabular}{lccccccc}
\hline \hline $\begin{array}{l}\text { Annealing } \\
\text { temperature }\left({ }^{\circ} \mathrm{C}\right)\end{array}$ & $a(\AA)$ & $c(\AA)$ & $c l a$ & Unit cell volume $\left(\AA^{3}\right)$ & $\left.I_{(003)}\right) I_{(104)}$ & Average crystal size $(\mathrm{nm})$ & Surface area $\left(\mathrm{m}^{2} / \mathrm{g}\right)$ \\
\hline 750 & $2.848(1)$ & $14.014(0)$ & $4.920(3)$ & $98.444(0)$ & 1.09 & $28.3 \pm 6$ & 6.13 \\
850 & $2.852(0)$ & $14.057(1)$ & $4.929(0)$ & $99.009(0)$ & 1.28 & $166 \pm 18$ & 1.58 \\
950 & $2.856(2)$ & $14.073(3)$ & $4.927(2)$ & $99.425(0)$ & 1.49 & $458 \pm 34$ & 0.41 \\
1000 & $2.856(1)$ & $14.026(2)$ & $4.911(0)$ & $99.082(3)$ & 1.47 & $850 \pm 50$ & 0.09 \\
\hline \hline
\end{tabular}

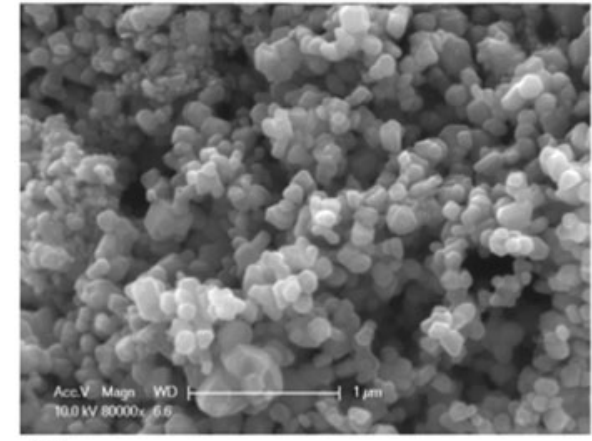

(a)

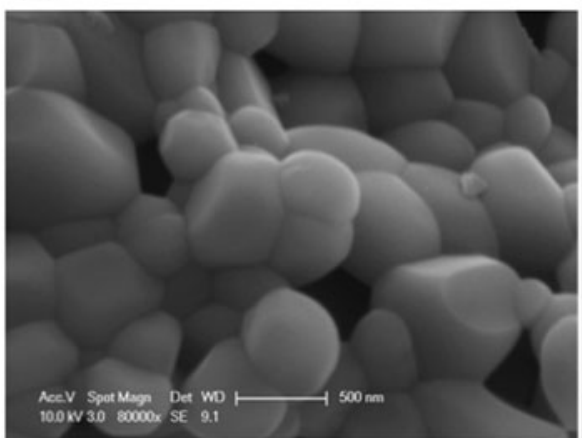

(c)

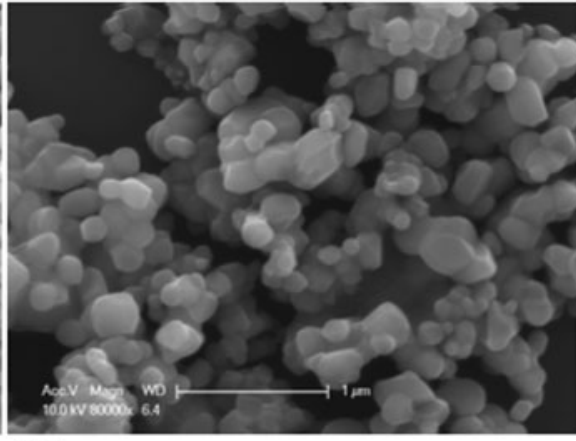

(b)

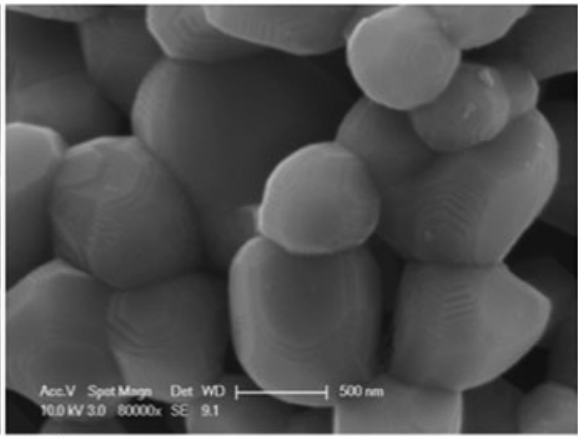

(d)

FIG. 2. SEM micrographs of $\mathrm{Li}\left[\mathrm{Ni}_{1 / 3} \mathrm{Co}_{1 / 3} \mathrm{Mn}_{1 / 3}\right] \mathrm{O}_{2}$ annealed in air for $3 \mathrm{~h}$ at (a) $750{ }^{\circ} \mathrm{C}$, (b) $850{ }^{\circ} \mathrm{C}$, (c) $950{ }^{\circ} \mathrm{C}$, and (d) $1000{ }^{\circ} \mathrm{C}$.

significant crystal growth of L333 between 750 and $1000{ }^{\circ} \mathrm{C}$. Specifically, specimens heated to $750{ }^{\circ} \mathrm{C}$ demonstrated a nanocrystalline nature (i.e., crystal diameters less than $50 \mathrm{~nm}$ ) as determined by analyses of the FWHM from XRD patterns. These crystals grow in size with increased temperature up to $166 \mathrm{~nm}$ by $850^{\circ} \mathrm{C}, 458 \mathrm{~nm}$ by $950{ }^{\circ} \mathrm{C}$, and eventually to $850 \mathrm{~nm}$ by $1000{ }^{\circ} \mathrm{C}$ (Table I). It is evident that annealing at lower temperatures [i.e., Figs. 2(a)-2(c)] yields a more uniform size distribution than at $1000{ }^{\circ} \mathrm{C}$ [Fig. 2(d)]. Thus, the annealing temperature not only affects the crystal size but also changes the particle size dispersity.

\section{B. Electrochemical performance}

Figure 3 shows representative CV curves of samples annealed under different temperatures. Each of these curves displays only one oxidation peak and reduction peak, corresponding to the charge/discharge reactions of the $\mathrm{Ni}^{2+} / \mathrm{Ni}^{4+}$ redox couple. ${ }^{30,31}$ The lack of a peak

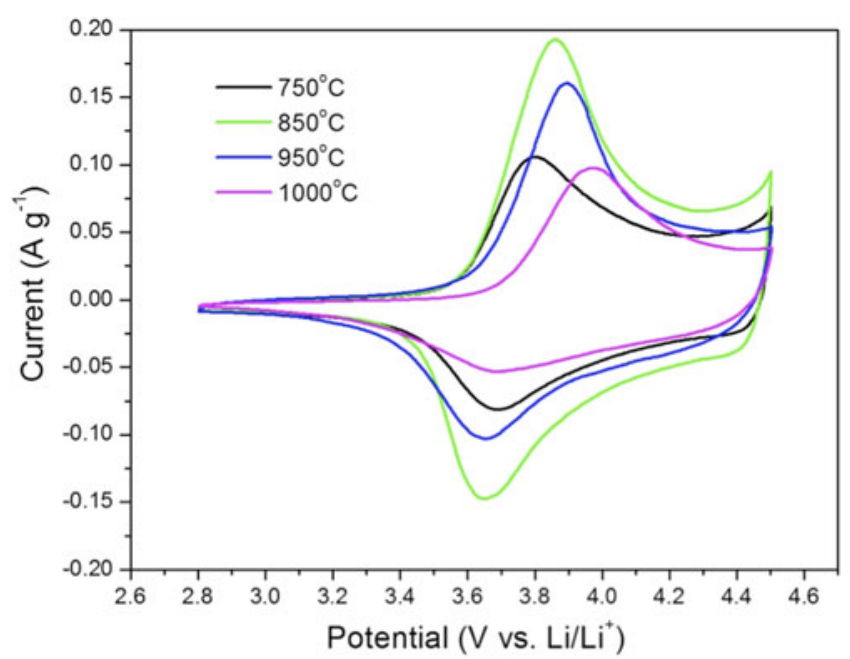

FIG. 3. $\mathrm{CV}$ profiles of $\mathrm{Li}\left[\mathrm{Ni}_{1 / 3} \mathrm{Co}_{1 / 3} \mathrm{Mn}_{1 / 3}\right] \mathrm{O}_{2}$ (annealed in air for $3 \mathrm{~h}$ at various temperatures) in the voltage range of $2.8-4.5 \mathrm{~V}$ at a scan rate of $0.1 \mathrm{mV} / \mathrm{s}$. 
at $3 \mathrm{~V}$ indicates the absence of $\mathrm{Mn}^{3+}$ in the as-synthesized material. $^{32,33}$ The potential separations between the anode and cathode peaks are at $0.12,0.21,0.24$, and $0.28 \mathrm{~V}$ for samples annealed at $750,850,950$, and $1000{ }^{\circ} \mathrm{C}$, respectively. Here, there is an increased peak separation, which indicates a decreased rate constant for charge transfer due to the increasing crystalline sizes for specimens annealed at $750-1000{ }^{\circ} \mathrm{C}$. In addition, samples treated at 850 and $950{ }^{\circ} \mathrm{C}$ display the highest peak currents $(0.19 \mathrm{~A} / \mathrm{g}$, and $0.16 \mathrm{~A} / \mathrm{g})$ compared to samples annealed at 750 and $1000{ }^{\circ} \mathrm{C}$. It is clear that samples treated at 850 and $950{ }^{\circ} \mathrm{C}$ which show smaller

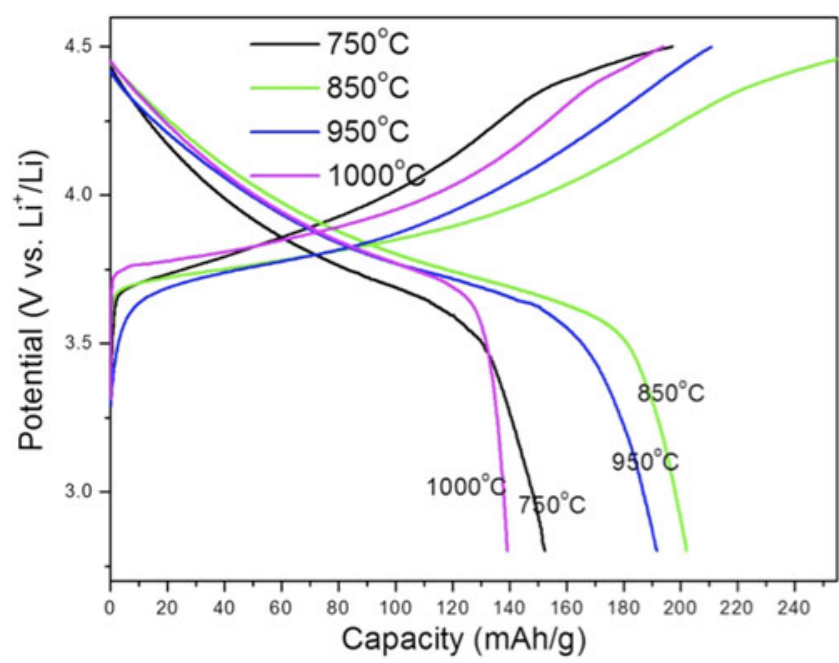

FIG. 4. Initial charge/discharge profiles of $\mathrm{Li}\left[\mathrm{Ni}_{1 / 3} \mathrm{Co}_{1 / 3} \mathrm{Mn}_{1 / 3}\right] \mathrm{O}_{2}$ samples at $16 \mathrm{~mA} \mathrm{~g}^{-1}$ (synthesized at different annealing temperatures) in the voltage range of $2.8-4.5 \mathrm{~V}$. voltage differences between the charge and discharge as well as higher peak currents indicate better electrode reaction kinetics and rate performance. ${ }^{34,35}$

The initial charge/discharge profiles of cells with different L333 cathode crystal sizes are illustrated in Fig. 4. The first discharge capacities are 155.1, 204.7, 191.6, and $139.3 \mathrm{~mA} \mathrm{~h} / \mathrm{g}$ at $750,850,950$, and $1000{ }^{\circ} \mathrm{C}$, respectively. Here the discharge capacities are comparable or even better than those currently reported. ${ }^{36}$ The discharge plateaus for samples annealed at 850 and $950{ }^{\circ} \mathrm{C}$ are longer compared to the other two samples, indicating the increased kinetics of these cathodes with increased annealing temperatures.

Further cycling charge-discharge capacities were measured at $0.1 \mathrm{C}$ for 10 cycles followed by 10 cycles at $0.2 \mathrm{C}, 0.5 \mathrm{C}, 1 \mathrm{C}$, and $2 \mathrm{C}$. Figure 5 (a) clearly demonstrates that the sample annealed at $850{ }^{\circ} \mathrm{C}$ delivers the highest discharge capacity. Although the discharge capacity inevitably decreases with increasing current density, cathodes annealed at $850{ }^{\circ} \mathrm{C}$ in air for $3 \mathrm{~h}$ delivered a discharge capacity of $119.9 \mathrm{~mA} \mathrm{~h} / \mathrm{g}$ at $2 \mathrm{C}$ (Table II), comparable with a carbon coated L333 system. ${ }^{37}$ By comparing the samples annealed at 950 and $1000{ }^{\circ} \mathrm{C}$, which have similar cation ordering $\left(I_{(003)} / I_{(104)}=1.49\right.$ and 1.47 , respectively $)$, the smaller crystal size $\left(458 \mathrm{~nm}\right.$ at $\left.950{ }^{\circ} \mathrm{C}\right)$ displays a higher capacity than larger ones $\left(850 \mathrm{~nm}\right.$ at $\left.1000{ }^{\circ} \mathrm{C}\right)$ due to the increased surface area and the decreased diffusion path for lithium ions.

Further calculations (Table II) show that the capacity difference between samples annealed at 850 and $950{ }^{\circ} \mathrm{C}$ is smaller $(\sim 15 \mathrm{~mA} \mathrm{~h} / \mathrm{g})$ at low current densities (from 0.1 to $0.5 \mathrm{C}$ ), but increases to $30 \mathrm{~mA} \mathrm{~h} / \mathrm{g}$ at $1 \mathrm{C}$
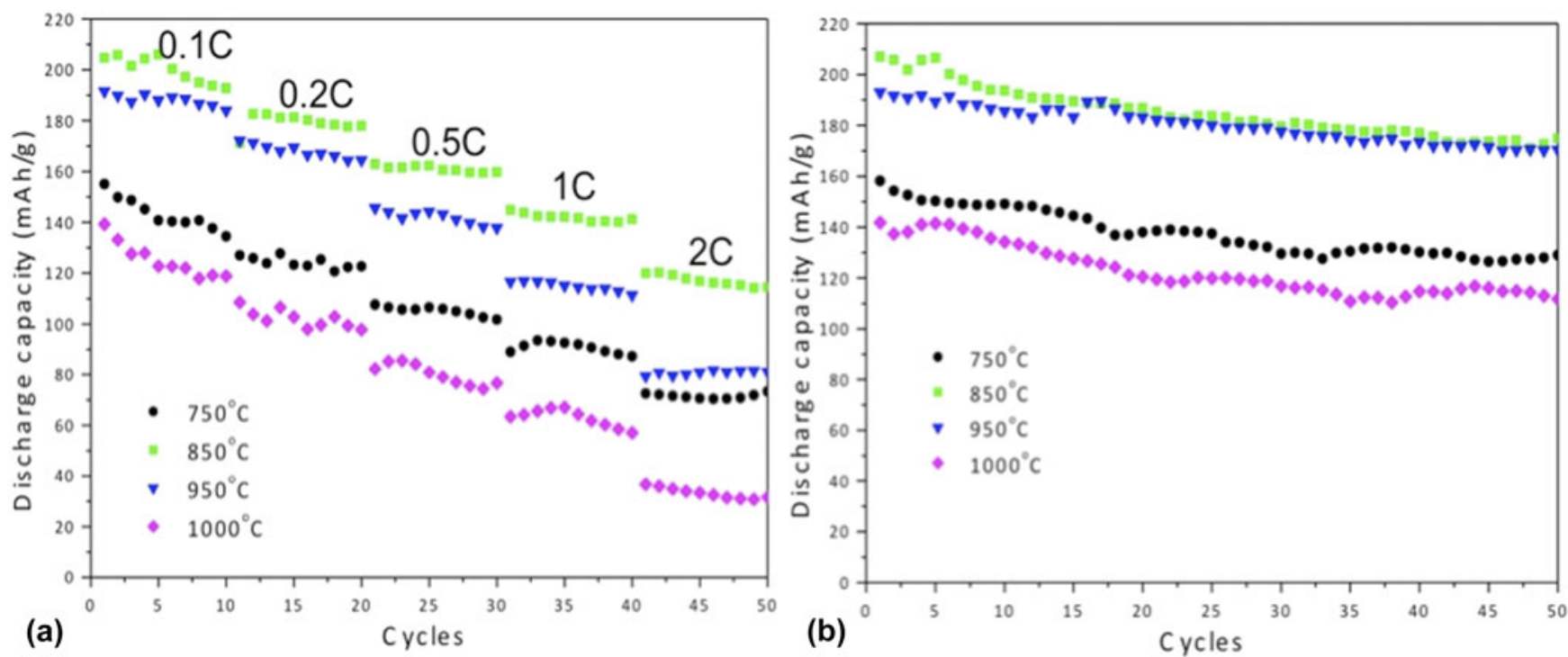

FIG. 5. Cycling performance of $\mathrm{Li}\left[\mathrm{Ni}_{1 / 3} \mathrm{Co}_{1 / 3} \mathrm{Mn}_{1 / 3}\right] \mathrm{O}_{2}$ cathodes between 2.8 and $4.5 \mathrm{~V}$ (versus $\mathrm{Li}^{+} / \mathrm{Li}$ ) (a) at different current rates $(0.1 \mathrm{C}, 0.2 \mathrm{C}$, $0.5 \mathrm{C}, 1 \mathrm{C}$, and $2 \mathrm{C}$ ); (b) discharge capacity at $0.1 \mathrm{C}$ over 50 cycles. 
and $40 \mathrm{mAh} / \mathrm{g}$ at $2 \mathrm{C}$. Therefore, the smaller crystal size is beneficial under high rates.

The similar phenomenon was also reported by the other researchers in their nanomaterial system. ${ }^{38}$ This is because the increased surface area provides increased interfaces between the electrolyte and the active material, at the same time, the smaller particle sizes shorten the diffusion path of lithium ions from the surface to the interior of particles, therefore delivering high capacity, especially at high rates. Figure 5(b) displays the cycling stability at $0.1 \mathrm{C}$ for all samples. Clearly, the 850 and $950{ }^{\circ} \mathrm{C}$ samples carry higher discharge capacities with higher capacity retention $\left(84 \%\right.$ for $850{ }^{\circ} \mathrm{C}$ and $88 \%$ for $\left.950{ }^{\circ} \mathrm{C}\right)$ compared with the other two samples $(81 \%$ for $750{ }^{\circ} \mathrm{C}$ and $79 \%$ for $1000{ }^{\circ} \mathrm{C}$ ) after 50 cycles.

TABLE II. Specific capacities for $\mathrm{Li}\left[\mathrm{Ni}_{1 / 3} \mathrm{Co}_{1 / 3} \mathrm{Mn}_{1 / 3}\right] \mathrm{O}_{2}$ cathodes annealed at various temperatures for $3 \mathrm{~h}$.

\begin{tabular}{lcrrrr}
\hline \hline \multirow{2}{*}{$\begin{array}{l}\text { Annealing } \\
\text { temperature }\left({ }^{\circ} \mathrm{C}\right)\end{array}$} & \multicolumn{5}{c}{ Specific capacity $(\mathrm{mAh} / \mathrm{g})$} \\
\cline { 2 - 6 } & $0.1 \mathrm{C}$ & $0.2 \mathrm{C}$ & \multicolumn{1}{c}{$0.5 \mathrm{C}$} & \multicolumn{1}{c}{$1 \mathrm{C}$} & \multicolumn{1}{c}{$2 \mathrm{C}$} \\
\hline 750 & 155.05 & 127.03 & 107.54 & 89.02 & 72.46 \\
850 & 204.77 & 188.26 & 162.99 & 144.84 & 119.92 \\
950 & 191.61 & 172.17 & 145.62 & 116.60 & 79.30 \\
1000 & 139.28 & 108.47 & 82.30 & 63.44 & 36.68 \\
\hline \hline
\end{tabular}

\section{Degradation}

To investigate the degradation in performance for $\mathrm{Li}\left[\mathrm{Ni}_{1 / 3} \mathrm{Co}_{1 / 3} \mathrm{Mn}_{1 / 3}\right] \mathrm{O}_{2}$ cathodes annealed at different temperatures, we disassembled the cells after 50 cycles and collected the cathode materials from the Al foil. The mixture was rinsed with NMP several times to remove the PVDF binder and the remaining organic solvents from the electrolyte. The material was subsequently dried in the vacuum oven for 2 days at room temperature and then subjected to XRD and SEM characterization. Figure 6 demonstrates the SEM micrographs of cathodes removed from the cells after 50 cycles. Based on analyses by EDS, smaller particles in each micrograph are mostly carbon that was mixed during the cell preparation.

The particles that were annealed at 750 and $850{ }^{\circ} \mathrm{C}$ did not show obvious structural changes [Figs. 6(a) and 6(b), respectively]. However, some evidence of banding was observed in a few particles [see yellow arrows in Fig. 6(b)]. Small cracks appeared in particles annealed at $950{ }^{\circ} \mathrm{C}$ [Fig. 6(c)] and the significantly larger cracks and fractured particles were observed in samples annealed at $1000{ }^{\circ} \mathrm{C}$ [Fig. 6(d)]. To study the crystal microstructure change, we conducted the further XRD analyses to calculate the lattice parameters and volume changes.

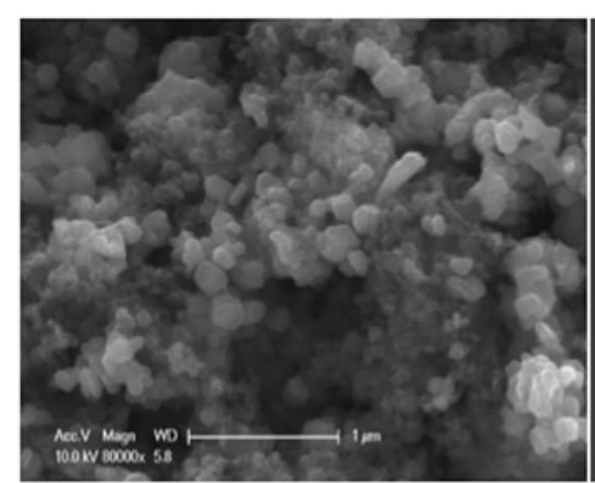

(a)

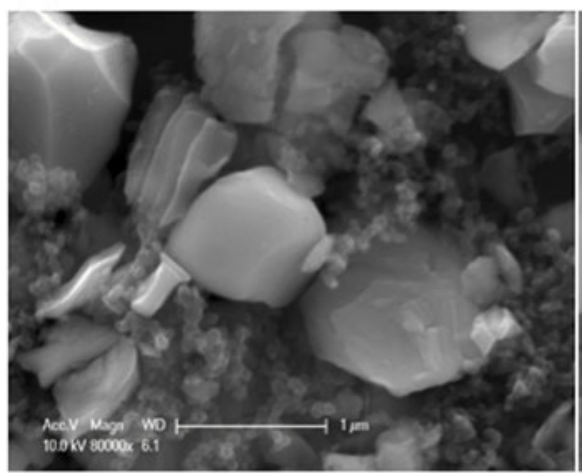

(c)

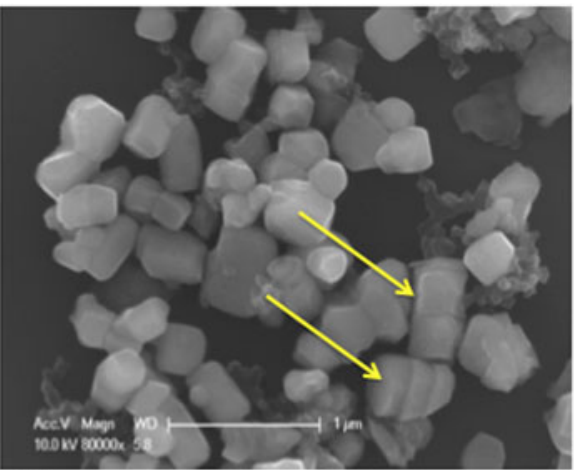

(b)

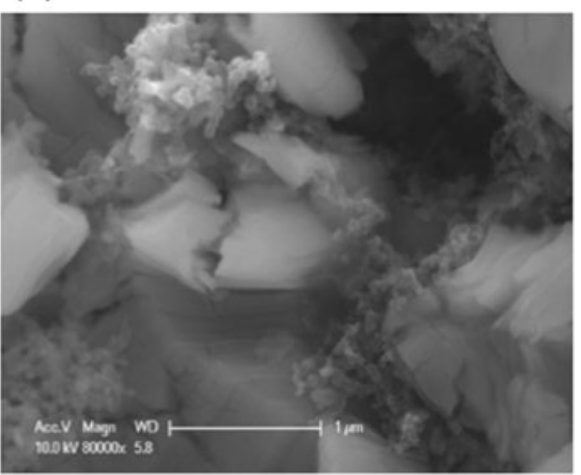

(d)

FIG. 6. SEM micrographs of $\mathrm{Li}\left[\mathrm{Ni}_{1 / 3} \mathrm{Co}_{1 / 3} \mathrm{Mn}_{1 / 3}\right] \mathrm{O}_{2}$ cathode particles, annealed in air for $3 \mathrm{~h}$ at (a) $750{ }^{\circ} \mathrm{C}$, (b) $850{ }^{\circ} \mathrm{C}$, (c) $950{ }^{\circ} \mathrm{C}$, and (d) $1000{ }^{\circ} \mathrm{C}$, and removed from cells after 50 charge-discharge cycles. Yellow arrows in (b) show particles that appear banded due to strain. 
Figure 7 show the XRD patterns for noncycled $\mathrm{Li}\left[\mathrm{Ni}_{1 / 3} \mathrm{Co}_{1 / 3} \mathrm{Mn}_{1 / 3}\right] \mathrm{O}_{2}$ samples (black line) and after 50 cycles (blue line). It can be seen that some of the peaks shifted to lower 2-theta values after cycling, indicating an increased lattice parameter and expanded volume. As discussed earlier, the peak splitting for the (006)/(102) and (108)/(110) reflections represents a well-ordered layered structure. After 50 cycles, the extent of splitting of peaks did not appear to change for specimens annealed at 750 and $850{ }^{\circ} \mathrm{C}$. However, the intensity of the splitting decreased for the sample annealed at $950{ }^{\circ} \mathrm{C}$ [Fig. 7(c)] and was especially significant in the first peak splitting $((006) /(102)$ reflections). The sample annealed at $1000{ }^{\circ} \mathrm{C}$ [Fig. 7(d)] showed a further decrease in peak intensity, with almost no splitting observed. These analyses are consistent with our SEM observations.

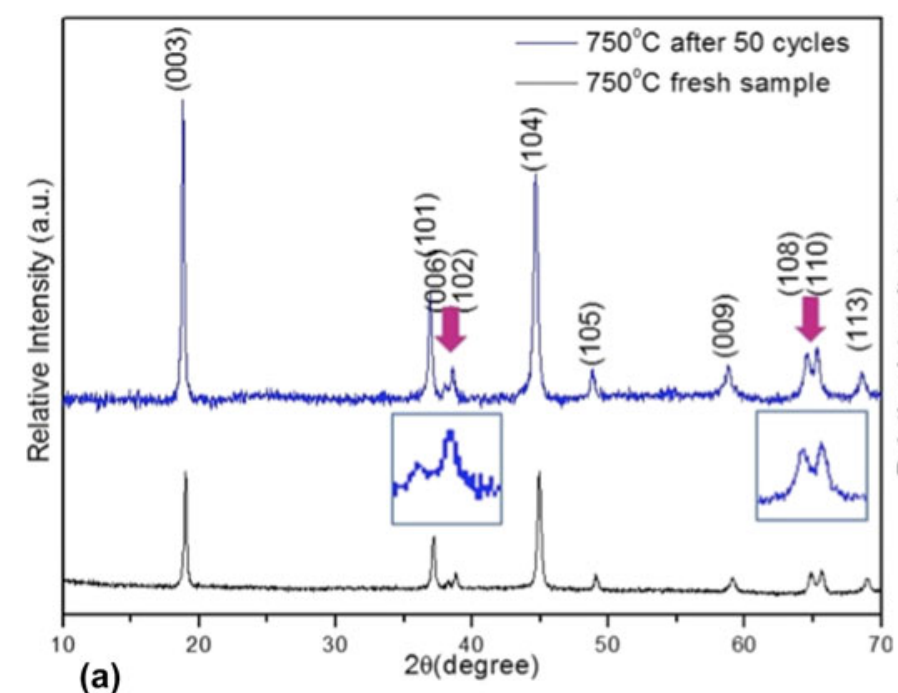

(a)

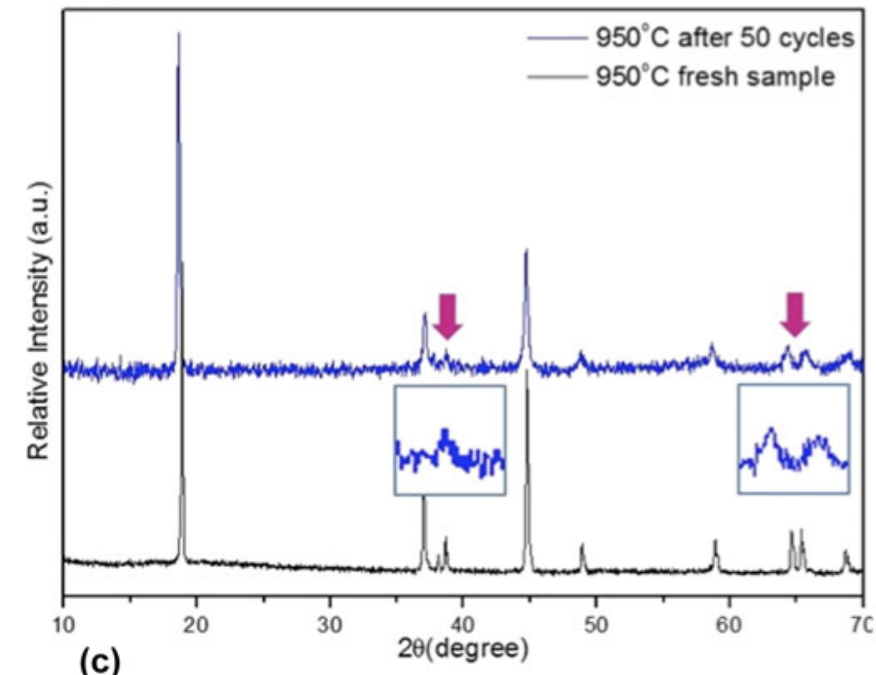

Detailed lattice parameters are listed in Table III, from which we can see that the $1000{ }^{\circ} \mathrm{C}$ cathode shows the largest lattice parameter increase and volume expansion (2.15\%), while samples annealed at 850 and $950{ }^{\circ} \mathrm{C}$ display minimal changes. Here, we also observed that the percent change in the "a" lattice parameter (i.e., $<0.5 \%$ ) is significantly less compared to those occurring in the "c" $(\sim 1$ or $>1 \%)$, indicating anisotropic degradation in the L333 system. It is known that lithium ions move along the ab plane in L333 during lithiation and delithiation. Thus, we suspect that parameter $c$ change in this crystal structure degradation is comparably a mild effect to the performance compared to changes along $a$ and $b$. By combining the above SEM and XRD analyses with charge-discharge cycling performance, it is clear that smaller particle sizes will yield smaller structural changes and thus, better strain accommodation, which
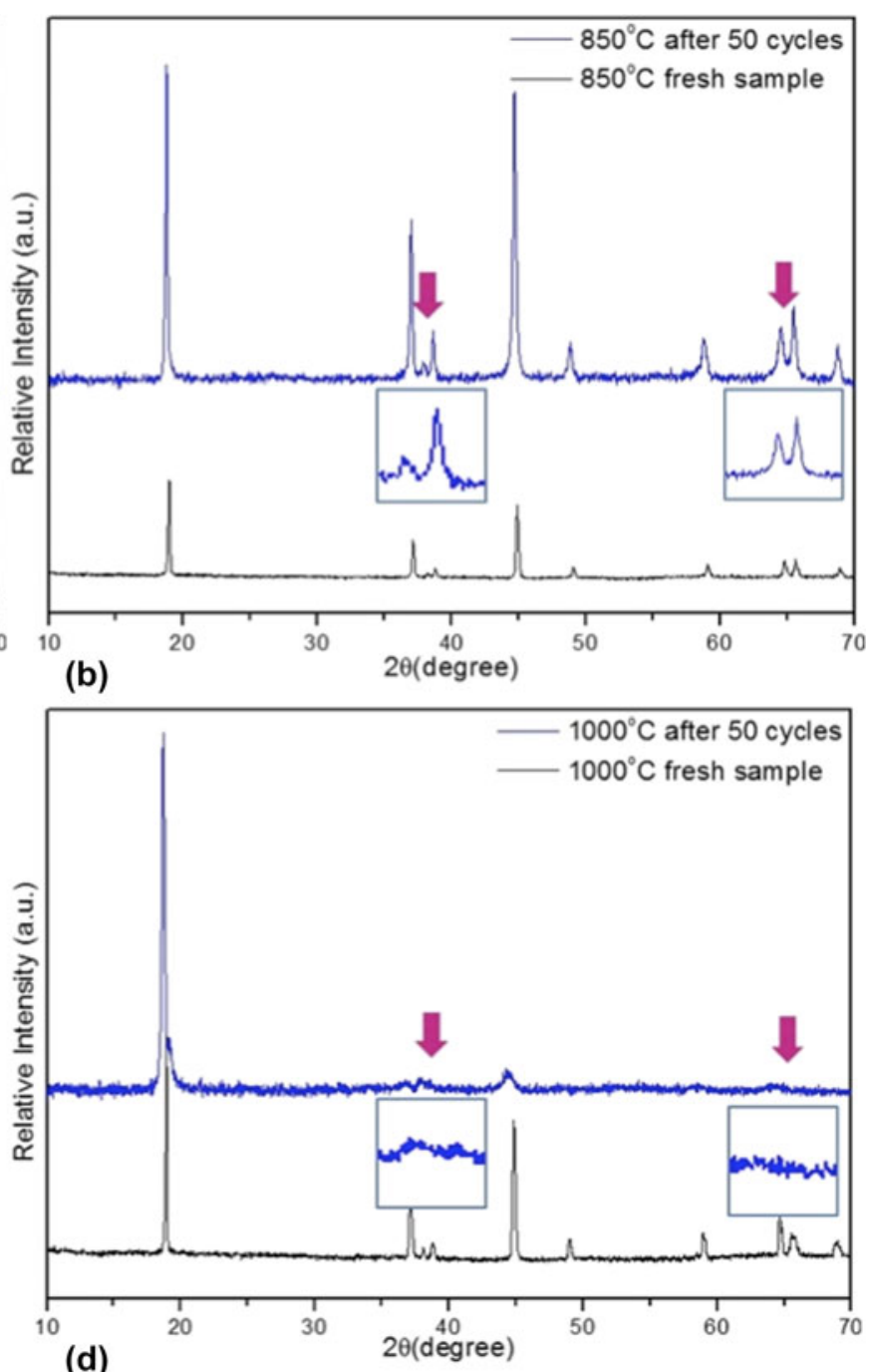

FIG. 7. Comparisons of cation ordering via XRD for $\mathrm{Li}\left[\mathrm{Ni}_{1 / 3} \mathrm{Co}_{1 / 3} \mathrm{Mn}_{1 / 3}\right] \mathrm{O}_{2}$ samples annealed in air for $3 \mathrm{~h}$ at: (a) $750{ }^{\circ} \mathrm{C}$, (b) $850{ }^{\circ} \mathrm{C},(\mathrm{c}) 950{ }^{\circ} \mathrm{C}$, and (d) $1000{ }^{\circ} \mathrm{C}$, before (black) and after (blue) cycling with enlarged area highlighted to show peak splitting. 
TABLE III. Lattice parameters for $\mathrm{Li}\left[\mathrm{Ni}_{1 / 3} \mathrm{Co}_{1 / 3} \mathrm{Mn}_{1 / 3}\right] \mathrm{O}_{2}$ cathodes after 50 cycles.

\begin{tabular}{|c|c|c|c|c|c|c|c|}
\hline Sample & $\begin{array}{c}a \\
(\AA)\end{array}$ & $\begin{array}{r}\Delta a / a \\
(\%)\end{array}$ & $\begin{array}{c}c \\
(\AA)\end{array}$ & $\begin{array}{c}\Delta c / c \\
(\%)\end{array}$ & $a / c$ & $\begin{array}{c}V \\
\left(\AA^{3}\right)\end{array}$ & $\begin{array}{c}\Delta V / V \\
(\%)\end{array}$ \\
\hline $750{ }^{\circ} \mathrm{C}$ & $2.858(0)$ & 0.35 & $14.144(0)$ & 0.93 & $4.949(0)$ & $100.039(1)$ & 1.62 \\
\hline $850{ }^{\circ} \mathrm{C}$ & $2.852(1)$ & 0.004 & 14.189(4) & 0.93 & $4.976(1)$ & 99.915(0) & 0.92 \\
\hline $950{ }^{\circ} \mathrm{C}$ & $2.859(0)$ & 0.11 & $14.205(2)$ & 0.94 & $4.969(0)$ & $100.538(3)$ & 1.12 \\
\hline $1000^{\circ} \mathrm{C}$ & $2.868(0)$ & 0.42 & $14.213(4)$ & 1.33 & $4.956(7)$ & $101.211(4)$ & 2.15 \\
\hline
\end{tabular}

is also observed in $\mathrm{LiCoO}_{2}$ cathodes as well as $\mathrm{Si}$-based anodes. ${ }^{39-42}$ According to Liu et al., ${ }^{39}$ there exists a critical particle size of $\sim 150 \mathrm{~nm}$ below which cracking did not occur, and above which surface cracking and particle fracture took place upon lithiation. The unexpected surface cracking is attributed to the development of hoop tension in the surface layer, resulting from a unique lithiation mechanism in crystalline Si nanoparticles by means of motion of a two-phase interface. In the study of Zhao et al., ${ }^{42}$ the inhomogeneous distribution of lithium in $\mathrm{LiCoO}_{2}$ results in stresses that may cause the particle to fracture. This might also apply to the L333 system based on the similar results, which is currently under investigation. One exception to this was the sample annealed at $750{ }^{\circ} \mathrm{C}$. In this sample, it is believed that reduced ordering in the noncycled layered structure $\left(I_{(003)} / I_{(104)}=1.19\right)$ yielded poorer performance compared to samples annealed at 850 and $950{ }^{\circ} \mathrm{C}$.

In Figs. 7(c) and 7(d), it is clear that the intensity of some high index/low intensity crystallographic reflections was reduced or eliminated after extended electrochemical cycling (i.e., 50 cycles). For example, we observed that the (009) reflection in the $1000{ }^{\circ} \mathrm{C}$ annealed specimen almost completely disappears after 50 cycles. Careful observation of particles from Figs. 6(b)-6(d) reveals that many of the fractures initiate in specimens annealed at lower temperature (i.e., $850{ }^{\circ} \mathrm{C}$ ) and are significantly exacerbated in specimens annealed at higher temperature (e.g., $1000{ }^{\circ} \mathrm{C}$ ). Since lithium intercalation and deintercalation occur between metal oxide layers, which are parallel to (001) planes, there are stresses developed due to volumetric strain. Thus, cracks are likely to develop along these planes. In fact, Fig. 6(b) shows a few particles that are apparently fracturing along parallel planes. During this fracture, it is clear that the severe fragmenting due to strain in larger crystals annealed at higher temperatures has reduced the faceting, fractured specimens along low index planes and subsequently reduced the intensities of higher order crystal reflections.

\section{CONCLUSIONS}

We have systematically investigated the effects of crystal structure and size on the performance of $\mathrm{Li}\left[\mathrm{Ni}_{1 / 3} \mathrm{Co}_{1 / 3} \mathrm{Mn}_{1 / 3}\right] \mathrm{O}_{2}$ cathodes. With increasing annealing temperature, $\mathrm{Li}\left[\mathrm{Ni}_{1 / 3} \mathrm{Co}_{1 / 3} \mathrm{Mn}_{1 / 3}\right] \mathrm{O}_{2}$ has the increased ordering of the hexagonal $\alpha-\mathrm{NaFeO}_{2}$ layered structure and increased crystallite sizes. Samples annealed at 850 and $950{ }^{\circ} \mathrm{C}$, which have clear peak splitting, higher cation ordering, and uniform crystal sizes, demonstrated better electrochemical performance. The higher cationic ordering provides better cycling performance for the crystal sizes below $500 \mathrm{~nm}$. In addition, crystal size has a key effect on the performance, especially for the high-current density discharge capacity. Due to the lower strain accommodation within the larger particles, cracks form in the microstructures during lithiation/delithiation, which results in a fast capacity fade.

\section{ACKNOWLEDGMENT}

This work is sponsored by the Winston Chung Global Energy Center.

\section{REFERENCES}

1. T. Ohzuku and Y. Makimura: Layered lithium insertion material of $\mathrm{LiCo}_{1 / 3} \mathrm{Ni}_{1 / 3} \mathrm{Mn}_{1 / 3} \mathrm{O}_{2}$ for lithium-ion batteries. Chem. Lett. 30, 642 (2001).

2. J. Choi and A. Manthiram: Role of chemical and structural stabilities on the electrochemical properties of layered $\mathrm{LiNi}_{1 / 3} \mathrm{Mn}_{1 / 3} \mathrm{Co}_{1 / 3} \mathrm{O}_{2}$ cathodes. J. Electrochem. Soc. 152, A1714 (2005).

3. K.M. Shaju and P.G. Bruce: Macroporous $\mathrm{Li}\left(\mathrm{Ni}_{1 / 3} \mathrm{Co}_{1 / 3} \mathrm{Mn}_{1 / 3}\right) \mathrm{O}_{2}$ : A high-power and high-energy cathode for rechargeable lithium batteries. Adv. Mater. 18, 2330 (2006).

4. N. Yabuuchi, Y. Makimura, and T. Ohzuku: Solid-state chemistry and electrochemistry of $\mathrm{LiCo}_{1 / 3} \mathrm{Ni}_{1 / 3} \mathrm{Mn}_{1 / 3} \mathrm{O}_{2}$ for advanced lithium-ion batteries III. Rechargeable capacity and cycleability. J. Electrochem. Soc. 154, A314 (2007).

5. Z.H. Lu, D.D. MacNeil, and J.R. Dahn: Layered $\mathrm{LiNi}_{\mathrm{x}} \mathrm{Co}_{1-2 \mathrm{x}} \mathrm{Mn}_{\mathrm{x}} \mathrm{O}_{-2}$ cathode materials for lithium-ion batteries. Electrochem. Solid-State Lett. 4, A200 (2001).

6. B.J. Hwang, Y.W. Tsai, D. Carlier, and G.A. Ceder: Combined computational/experimental study on $\mathrm{LiNi}_{1 / 3} \mathrm{Co}_{1 / 3} \mathrm{Mn}_{1 / 3} \mathrm{O}_{2}$. Chem. Mater. 15, 3676 (2003).

7. I. Belharouak, Y.K. Sun, J. Liu, and K. Amine: $\mathrm{Li}\left(\mathrm{Ni}_{1 / 3} \mathrm{Co}_{1 / 3} \mathrm{Mn}_{1 / 3}\right) \mathrm{O}_{2}$ as a suitable cathode for high power applications. J. Power Sources 123, 247 (2003).

8. H. Ren, X. Mu, Y. Huang, Z. Li, Y. Wang, P. Cai, Z. Peng, and Y. Zhou: Effects of Sn doping on electrochemical characterizations of $\mathrm{Li}\left(\mathrm{Ni}_{1 / 3} \mathrm{Co}_{1 / 3} \mathrm{Mn}_{1 / 3}\right) \mathrm{O}_{2}$ cathode material. Ionics 16, 497 (2010).

9. S.H. Kim, K.B. Shim, K.R. Han, and C-S. Kim: Electrochemical properties of $\mathrm{Al}$ doped $\mathrm{Li}\left(\mathrm{Ni}_{1 / 3} \mathrm{Co}_{1 / 3} \mathrm{Mn}_{1 / 3}\right) \mathrm{O}_{2}$. In Advances in Nanomaterials and Processing, Pts 1 and 2, B.T. Ahn, H. Jeon, B.Y. Hur, K. Kim, and J.W. Park eds.; (Trans Tech Publications Ltd., Stafa-Zurich, 2007), Vol. 124-126, pp. 1023-1026.

10. S.Y. Yang, X-Y. Wang, Z-L. Liu, Q-Q. Chen, X-K. Yang, and Q-L. Wei: Influence of pretreatment process on structure, morphology and electrochemical properties of $\mathrm{Li}\left(\mathrm{Ni}_{1 / 3} \mathrm{Co}_{1 / 3} \mathrm{Mn}_{1 / 3}\right) \mathrm{O}_{2}$ cathode material. Trans. Nonferrous Met. Soc. China 21, 1995 (2011).

11. B. Lin, Z. Wen, Z. Gu, and S. Huang: Morphology and electrochemical performance of $\mathrm{Li}\left(\mathrm{Ni}_{1 / 3} \mathrm{Co}_{1 / 3} \mathrm{Mn}_{1 / 3}\right) \mathrm{O}_{2}$ cathode material by a slurry spray drying method. J. Power Sources 175, 564 (2008). 
12. S.H. Yun, K-S. Park, and Y.J. Park: The electrochemical property of $\mathrm{ZrFx}$-coated $\mathrm{Li}\left(\mathrm{Ni}_{1 / 3} \mathrm{Co}_{1 / 3} \mathrm{Mn}_{1 / 3}\right) \mathrm{O}_{2}$ cathode material. J. Power Sources 195, 6108 (2010).

13. B. Lin, Z. Wen, J. Han, and X. Wu: Electrochemical properties of carbon-coated $\mathrm{Li}\left(\mathrm{Ni}_{1 / 3} \mathrm{Co}_{1 / 3} \mathrm{Mn}_{1 / 3}\right) \mathrm{O}_{2}$ cathode material for lithium-ion batteries. Solid State Ionics 179, 1750 (2008).

14. Y. Huang, J. Chen, F. Cheng, W. Wan, W. Liu, H. Zhou, and $X$. Zhang: A modified $\mathrm{Al}_{2} \mathrm{O}_{3}$ coating process to enhance the electrochemical performance of $\mathrm{Li}\left(\mathrm{Ni}_{1 / 3} \mathrm{Co}_{1 / 3} \mathrm{Mn}_{1 / 3}\right) \mathrm{O}_{2}$ and its comparison with traditional $\mathrm{Al}_{2} \mathrm{O}_{3}$ coating process. J. Power Sources 195, 8267 (2010).

15. F. Wu, M. Wang, Y. Su, L. Bao, and S. Chen: A novel method for synthesis of layered $\mathrm{LiNi}_{1 / 3} \mathrm{Co}_{1 / 3} \mathrm{Mn}_{1 / 3} \mathrm{O}_{2}$ as cathode material for lithium-ion battery. J. Power Sources 195, 2362 (2010).

16. N. Yabuuchi and T. Ohzuku: Novel lithium insertion material of $\mathrm{LiCo}_{1 / 3} \mathrm{Ni}_{1 / 3} \mathrm{Mn}_{1 / 3} \mathrm{O}_{2}$ for advanced lithium-ion batteries. J. Power Sources 119, 171 (2003).

17. M.H. Lee, Y.J. Kang, S.T. Myung, and Y.K. Sun: Synthetic optimization of $\mathrm{Li}\left(\mathrm{Ni}_{1 / 3} \mathrm{Co}_{1 / 3} \mathrm{Mn}_{1 / 3}\right) \mathrm{O}_{2}$ via co-precipitation. Electrochim. Acta 50, 939 (2004).

18. Y. Ding, P. Zhang, Y. Jiang, and D. Gao: Effect of rare earth elements doping on structure and electrochemical properties of $\mathrm{LiNi}_{1 / 3} \mathrm{Co}_{1 / 3} \mathrm{Mn}_{1 / 3} \mathrm{O}_{2}$ for lithium-ion battery. Solid State Ionics 178, 967 (2007).

19. J. Guo, L.F. Jiao, H. Yuan, L.Q. Wang, H.X. Li, M. Zhang, and Y.M. Wang: Effect of structural and electrochemical properties of different Cr-doped contents of $\mathrm{Li}\left[\mathrm{Ni}_{1 / 3} \mathrm{Co}_{1 / 3} \mathrm{Mn}_{1 / 3}\right] \mathrm{O}_{2}$. Electrochim. Acta 51, 6275 (2006).

20. J. Xie, X. Huang, Z. Zhu, and J. Dai: Hydrothermal synthesis of $\mathrm{Li}\left(\mathrm{Ni}_{1 / 3} \mathrm{Co}_{1 / 3} \mathrm{Mn}_{1 / 3}\right) \mathrm{O}_{2}$ for lithium rechargeable batteries. Ceram. Int. 36, 2485 (2010).

21. C. Venkateswara Rao, A. Leela Mohana Reddy, Y. Ishikawa, and P.M. Ajayan: $\mathrm{LiNi}_{1 / 3} \mathrm{Co}_{1 / 3} \mathrm{Mn}_{1 / 3} \mathrm{O}_{2}$-Graphene composite as a promising cathode for lithium-ion batteries. ACS Appl. Mater. Interfaces 3, 2966 (2011).

22. R. Guo, P. Shi, X. Cheng, and C. Du: Synthesis and characterization of carbon-coated $\mathrm{LiNi}_{1 / 3} \mathrm{Co}_{1 / 3} \mathrm{Mn}_{1 / 3} \mathrm{O}_{2}$ cathode material prepared by polyvinyl alcohol pyrolysis route. J. Alloys Compd. 473, 53 (2009).

23. F. Wang, S. Xiao, Z. Chang, Y. Yang, and Y. Wu: Nanoporous $\mathrm{LiNi}_{1 / 3} \mathrm{Co}_{1 / 3} \mathrm{Mn}_{1 / 3} \mathrm{O}_{2}$ as an ultra-fast charge cathode material for aqueous rechargeable lithium batteries. Chem. Commun. 49, 9209 (2013).

24. J. Choi and A. Manthiram: Investigation of the irreversible capacity loss in the layered $\mathrm{LiNi}_{1 / 3} \mathrm{Co}_{1 / 3} \mathrm{Mn}_{1 / 3} \mathrm{O}_{2}$ cathodes. Electrochem. Solid-State Lett. 8, C102 (2005).

25. S. Kabi and A. Ghosh: Microstructure of $\mathrm{Li}\left(\mathrm{Mn}_{1 / 3} \mathrm{Ni}_{1 / 3} \mathrm{Co}_{1 / 3}\right) \mathrm{O}_{2}$ cathode material for lithium ion battery: Dependence of crystal structure on calcination and heat-treatment temperature. Mater. Res. Bull. 48, 3405 (2013).

26. J. Zhu, T. Vo, D. Li, R. Lu, N.M. Kinsinger, L. Xiong, Y. Yan, and D. Kisailus: Crystal growth of $\mathrm{Li}\left(\mathrm{Ni}_{1 / 3} \mathrm{Co}_{1 / 3} \mathrm{Mn}_{1 / 3}\right) \mathrm{O}_{2}$ as a cathode material for high-performance lithium ion batteries. Cryst. Growth Des. 12, 1118 (2012).
27. H.V. Atkinson: Theories of normal grain-growth in pure single-phase systems. Acta Metall. 36, 469 (1988).

28. D. Weaire and N. Rivier: SOAP, cells and statistics-random patterns in 2 dimensions. Contemp. Phys. 25, 59 (1984).

29. J.N. Reimers, J.R. Dahn, J.E. Greedan, C.V. Stager, G. Liu, I. Davidson, and U. Vonsacken: Spin-glass behavior in the frustrated antiferromagnetic $\mathrm{LiNiO}_{2}$. J. Solid State Chem. 102, 542 (1993).

30. J.M. Kim and H.T. Chung: Role of transition metals in layered $\mathrm{Li}[\mathrm{Ni}, \mathrm{Co}, \mathrm{Mn}] \mathrm{O}_{2}$ under electrochemical operation. Electrochim. Acta 49, 3573 (2004).

31. F. Wu, M. Wang, Y. Su, and S. Chen: Surface modification of $\mathrm{LiCo}_{1 / 3} \mathrm{Ni}_{1 / 3} \mathrm{Mn}_{1 / 3} \mathrm{O}_{2}$ with $\mathrm{Y}_{2} \mathrm{O}_{3}$ for lithium-ion battery. J. Power Sources 189, 743 (2009).

32. S. Gopukumar, K.Y. Chung, and K.B. Kim: Novel synthesis of layered $\mathrm{LiNi}_{1 / 2} \mathrm{Mn}_{1 / 2} \mathrm{O}_{2}$ as cathode material for lithium rechargeable cells. Electrochim. Acta 49, 803 (2004).

33. Y-S. He, Z-F. Ma, X-Z. Liao, and Y. Jiang: Synthesis and characterization of submicron-sized $\mathrm{LiNi}_{1 / 3} \mathrm{Co}_{1 / 3} \mathrm{Mn}_{1 / 3} \mathrm{O}_{2}$ by a simple self-propagating solid-state metathesis method. J. Power Sources 163, 1053 (2007).

34. Y. Lan, X. Wang, J. Zhang, J. Zhang, Z. Wu, and Z. Zhang: Preparation and characterization of carbon-coated $\mathrm{LiFePO}_{4}$ cathode materials for lithium-ion batteries with resorcinolformaldehyde polymer as carbon precursor. Powder Technol. 212, 327 (2011).

35. J. Zhu, J. Fiore, D. Li, N.M. Kinsinger, Q. Wang, E. DiMasi, J. Guo, and D. Kisailus: Solvothermal synthesis, development, and performance of $\mathrm{LiFePO}_{4}$ nanostructures. Cryst. Growth Des. 13, 4659 (2013).

36. P. Gao, Y.H. Li, H.D. Liu, J. Pinto, X.F. Jiang, and G. Yang: Improved high rate capacity and lithium diffusion ability of $\mathrm{LiNi}_{1 / 3} \mathrm{Co}_{1 / 3} \mathrm{Mn}_{1 / 3} \mathrm{O}_{2}$ with ordered crystal structure. J. Electrochem. Soc. 159, A506 (2012).

37. C-T. Hsieh, C-Y. Mo, Y-F. Chen, and Y-J. Chung: Chemical-wet synthesis and electrochemistry of $\mathrm{LiNi}_{1 / 3} \mathrm{Co}_{1 / 3} \mathrm{Mn}_{1 / 3} \mathrm{O}_{2}$ cathode materials for Li-ion batteries. Electrochim. Acta 106, 525 (2013).

38. W. Wang, I. Ruiz, S.R. Guo, Z. Favors, H.H. Bay, M. Ozkan, and C.S. Ozkan: Hybrid carbon nanotube and graphene nanostructures for lithium ion battery anodes. Nano Energy 3, 113 (2014).

39. X.H. Liu, L. Zhong, S. Huang, S.X. Mao, T. Zhu, and J.Y. Huang: Size-dependent fracture of silicon nanoparticles during lithiation. ACS Nano 6, 1522 (2012).

40. M. Ge, J. Rong, X. Fang, and C. Zhou: Porous doped silicon nanowires for lithium ion battery anode with long cycle life. Nano Lett. 12, 2318 (2012).

41. A.F. Bower, P.R. Guduru, and V.A. Sethuraman: A finite strain model of stress, diffusion, plastic flow, and electrochemical reactions in a lithium-ion half-cell. J. Mech. Phys. Solids 59, 804 (2011).

42. K. Zhao, M. Pharr, J.J. Vlassak, and Z. Suo: Fracture of electrodes in lithium-ion batteries caused by fast charging. J. Appl. Phys. 108, 073517 (2010) 